\title{
Timing of reproductive effort differs between young and old dominant male reindeer
}

\author{
Erica M. Tennenhouse ${ }^{1}$, Robert B. Weladji1 ${ }^{1, *}$, Øystein Holand ${ }^{2} \&$ \\ Mauri Nieminen ${ }^{3}$
}

1) Department of Biology, Concordia University, 7141 Sherbrooke St. West, Montreal, Quebec, H4B 1R6, Canada (*corresponding author's e-mail: rweladji@alcor.concordia.ca)

2) Department of Animal and Aquacultural Sciences, Norwegian University of Life Sciences, P.O. Box 5003, N-1432 Ås, Norway

3) Finnish Game and Fisheries Research Institute, Reindeer Research Station, Fl-99910 Kaamanen, Finland

Received 23 Feb 2011, final version received 17 Oct. 2012, accepted 3 Feb. 2012

Tennenhouse, E. M., Weladji, R. B., Holand, Ø. \& Nieminen, M. 2012: Timing of reproductive effort differs between young and old dominant male reindeer. - Ann. Zool. Fennici 49: 152-160.

In polygynous species, male reproductive effort has been measured both directly in the form of somatic costs and indirectly using behavioral data. We used 12 years of data collected from a semi-domesticated reindeer population in northern Finland to investigate age- and time-specific patterns of dominant males' reproductive effort. Overall, we found that activity levels differed both between young and old dominant reindeer males, and among the early, peak, and late rut, the pattern being age-specific. Reproductive effort was generally higher for old than young dominant males; however, old males reduced their effort in the late-rut period, while young males maintained the same level of activity. There was a positive relationship between somatic costs and activity level only during the early rut for young dominant males, and only during the peak rut for old dominant males. Thus, old males incur the highest energetic costs from rut-related activities when most of the females in the herd are in oestrus. Conversely, young males appear to time their rut-related energetic cost to coincide with the early rutting period, before most females have reached oestrus. Old males are more efficient in timing their reproductive effort so as to maximize their reproductive success. This can be attributed to young males being less experienced than old males or to using an alternative mating tactic by young males who try to avoid competition with old males during the peak rut.

\section{Introduction}

Life-history theory predicts that in iteroparous organisms as reproductive value declines, reproductive effort increases (Stearns 1992). This increase in reproductive effort may be a response to changes in reproductive value due to the period of the mating season or the age of the animal. Reproduction is an energetically expensive process. In particular, seasonally breeding polygynous males of large and highly dimorphic species have the opportunity to attain high reproductive success within a mating season (Emlen $\&$ Oring 1977), which often requires consider- 
able energy expenditure within a relatively short period of time (Michener \& McLean 1996). Furthermore, many seasonal breeders adopt a capital breeding tactic, in which resources are acquired prior to the mating season and food intake is drastically reduced during breeding (Jönsson 1997). As a result of an increased activity and reduced feeding, condition of males typically declines as the mating season progresses (Forsyth et al. 2005, Vannoni \& McElligott 2009). Substantial body mass loss over the mating season is also common among these species (Bobek et al. 1990, Mysterud et al. 2003). Decreased condition at the end of the mating season could negatively impact future ability to reproduce and survival (Neuhaus \& Pelletier 2001, Barboza et al. 2004).

Reproductive effort has been defined as an organism's investment into any current act of reproduction (Fisher 1930). Most empirical studies measure reproductive effort as an energetic cost (Clutton-Brock 1984, Nilsson \& Svensson 1996). For capital breeding mammals, the amount of weight lost over the mating season is considered a direct indicator of male reproductive effort (Yoccoz et al. 2002, Mysterud et al. 2005, Galimberti et al. 2007). Behavioural indices, such as performance of agonistic behaviours or activity budgets during the mating season, are also often used in studies as indirect measures of male reproductive effort (see references in Mysterud et al. 2004). Few studies have looked into the relationship between these two measures.

It has often been reported that old males lose substantially more weight than young males during the mating season (Skogland 1989, Mysterud et al. 2005). Proximally, this may be due to a combination of young males not participating in the capital breeding strategy (Apollonio \& Di Vittorio 2004, Mainguy \& Côté 2008), and engaging in less overall activity during the mating season than old males (Kojola 1991, Mainguy \& Côté 2008). There is also evidence that old and young males use different mating tactics, with old males sometimes engaging in more energetically costly tending of females (Saunders et al. 2005, Willisch \& Neuhaus 2009), while young males perform sneak copulations or engage in coursing (Willisch \& Neuhaus 2009), which are energetically expensive but infrequent.
There is evidence that large males are able to time their reproductive effort to coincide more precisely with female ovulation than small males (Preston et al. 2003). However, this study did not take into account that body size is typically correlated with age, and thus while precise timing of reproductive effort is size-dependent, it is also likely age-dependent. Indeed, many aspects of male reproduction, such as duration of male-male aggression (Jennings et al. 2004) and copulatory success (Apollonio et al. 1992) are affected by experience. Females might also control the timing of their ovulation to match the peak reproductive effort of the highest quality males; Komers et al. (1999) showed that female fallow deer enter oestrus earlier when adult males are present and delay oestrus when only young males are present.

In this study, we aimed to determine how reproductive effort varies with age and over the course of the mating season for dominant reindeer males (Rangifer tarandus). We predicted that old males would exhibit higher activity level, with peak activity coinciding with peak oestrus. Peak activity level for young males was predicted to occur before or after peak oestrus due to lack of experience or in order to avoid competing with old males. Finally, if the two commonly used measures of reproductive effort, somatic costs (measured as body mass loss during the rut) and activity level during the rut, are both reliable indicators of reproductive effort, a positive relationship between them was expected.

\section{Material and methods}

\section{Study area and research herd}

The data in the present study come from the Kutuharju Field Reindeer Station in Kaamanen, Finland $\left(69^{\circ} \mathrm{N}, 27^{\circ} \mathrm{E}\right)$. The total area of about $45 \mathrm{~km}^{2}$ is fenced and sub-divided into several smaller enclosures, among which Sinioivi $\left(\sim 15 \mathrm{~km}^{2}\right)$ and Lauluvaara $\left(\sim 13.8 \mathrm{~km}^{2}\right)$, the two largest, are used during the rut. This semi-domesticated reindeer population (approximately 100 animals) is free ranging for most of the year and has been continuously monitored since 1996 . At the beginning of the rut, all adults are fitted 
with VHF radio collars, which are marked with unique identification codes.

It has been established that male mating success in this herd is positively related to social rank (Holand et al. 2011). While dominant males sire a higher proportion of calves, subordinate males can also be successful in using alternative mating tactics such as sneak copulations (Roed et al. 2002). Between 1996 and 2008, females in this herd ranged from 1.5 to 12.5 years of age, and males ranged from 1.5 to 6.5 years of age (Table 1). The age structure of the herd is manipulated every year, and between 1996 and 2008 there were three age structures: young males only, old males only, and mixed (Table 1). Thus, it is possible for young males to be dominant as there are years when only young males are available during the breeding season.

\section{Data collection}

We used 12 years of data (1996-2008, excluding 1998 due to lack of data) for this study. Each year, fieldwork took place during the rutting period, which lasts three weeks between midSeptember and late October. We located the mating groups daily between 09:00 and 18:00 using ground tracking. Between two and five observers watched the group for five minutes, focusing on the males. Aggressive interactions among males as well as male rutting behaviours were observed, and the male winning most of the agonistic interactions and having control over females was considered to be the dominant male in the group (see Tennenhouse et al. 2011 for further details). All males were weighed to the nearest kilogram every year prior to (early to mid-September) and after (early November) the rutting season, and the birth dates of newborns were recorded during each calving season.

Throughout the mating season, instantaneous focal observations (Martin \& Bateson 2007) were taken on individuals within a mating group and recorded on check sheets. Typically we performed between one and five focal observations per animal per day. One focal observation consisted of 15 minutes of continuous observation of an animal, split into 15-second intervals. At the end of each interval, the activity being performed was categorized as: rest (lying down, sleeping or ruminating), stand (standing and not exhibiting motor behaviours or eating), walk (slow locomotion), eat (foraging), fight (exhibiting aggression with a partner), chase (pursuing a male, with one or both animals

Table 1. Annual sex composition and male age structure of semi-domesticated reindeer in the two experimental enclosures of the Kaamanen Experimental Reindeer Station, Finland, in 1996-2008 (1998 excluded due to lack of data). Three male age structures are used: $\mathrm{M}=$ Mixed age structure (i.e. young and old together), $\mathrm{Y}=$ young males only, and $\mathrm{A}=$ adult (old) males only.

\begin{tabular}{|c|c|c|c|c|c|c|c|c|c|}
\hline \multirow[t]{2}{*}{ Year } & \multirow[t]{2}{*}{ Location } & \multicolumn{2}{|c|}{ Number } & \multicolumn{5}{|c|}{ Number of males by age class (years) } & \multirow{2}{*}{$\begin{array}{l}\text { Male age } \\
\text { structure }\end{array}$} \\
\hline & & Females & Males & 1.5 & 2.5 & 3.5 & 4.5 & $>5$ & \\
\hline 1996 & Sinioivi & 43 & 6 & 3 & 0 & 0 & 3 & 0 & M \\
\hline 1996 & Lauluvaara & 46 & 6 & 6 & 0 & 0 & 0 & 0 & $\mathrm{Y}$ \\
\hline 1997 & Sinioivi & 47 & 18 & 9 & 6 & 0 & 0 & 3 & M \\
\hline 1997 & Lauluvaara & 47 & 4 & 4 & 0 & 0 & 0 & 0 & $Y$ \\
\hline 1999 & Sinioivi & 75 & 3 & 0 & 0 & 0 & 3 & 0 & $A$ \\
\hline 2000 & Sinioivi & 75 & 3 & 3 & 0 & 0 & 0 & 0 & $Y$ \\
\hline 2001 & Sinioivi & 80 & 11 & 11 & 0 & 0 & 0 & 0 & $Y$ \\
\hline 2002 & Sinioivi & 92 & 4 & 2 & 1 & 0 & 1 & 0 & $M$ \\
\hline 2003 & Sinioivi & 53 & 4 & 1 & 1 & 2 & 0 & 0 & $M$ \\
\hline 2004 & Sinioivi & 49 & 4 & 2 & 0 & 0 & 2 & 0 & $M$ \\
\hline 2005 & Sinioivi & 46 & 17 & 10 & 4 & 1 & 0 & 2 & $M$ \\
\hline 2006 & Sinioivi & 75 & 19 & 8 & 4 & 4 & 3 & 0 & $M$ \\
\hline 2007 & Sinioivi & 87 & 25 & 11 & 6 & 3 & 2 & 3 & $M$ \\
\hline 2008 & Sinioivi & 82 & 26 & 5 & 7 & 7 & 3 & 4 & $M$ \\
\hline 2008 & Lauluvaara & 82 & 26 & 5 & 7 & 7 & 3 & 4 & $M$ \\
\hline
\end{tabular}


exhibiting aggression and/or submission), herd female (pursuing a female until she returns to the mating group), spar (fighting in short bouts), displace (one male approaches another males, and the latter retreats), court (following a female or walking on her side while performing mating displays), copulation attempt (mounting a female without copulation) or copulation (mounting a female with thrusting of the pelvis). Walking, standing, eating and resting are performed considerably more frequently than any other behaviours. Since each behavioural observation period consisted of 60 intervals, we divided the sum of standing and walking intervals (active reproductive behaviors) by 60 to attain the proportion of performance of these behaviors relative to all other behaviors within that observation period; this was considered a male's activity level (see Tennenhouse et al. 2011 for a similar approach).

\section{Statistical analyses}

We divided the mating seasons, which lasted approximately three weeks each year, into three periods: early, peak, and late rut. The peak-rut day for each year was determined by subtracting the average gestation length for female reindeer in this population (221 days; Mysterud et al. 2009) from the birth date of each calf born in a given year. We considered the median peak-rut day for all females of a given year to be the overall peak-rut day for that year. To determine the peak-rut week, we added and subtracted three days from the peak-rut day. The early rut was the week prior to the peak-rut week, and the late rut was the week following the peak-rut week.

It has been shown that in this population, one- and two-year-old males lose significantly less weight over the mating season than do males older than two years (Tennenhouse et al. 2011). Thus for subsequent analyses, we sub-grouped males into two age classes: young (one-two years) and old ( $\geq$ three years) (see Tennenhouse et al. 2011).

We first assessed age- and time-specific patterns in activity level using mixed linear models (proc mixed in SAS ver. 9.1). We tested the effect of age class (factor with two levels: young and old), rutting period (factor with three levels: early rut, peak rut, and late rut) and their interaction (age class $\times$ period) on activity levels. If the interaction was significant, we further explored the pattern for each age class separately. Pair-wise multiple comparisons using a Tukey-Kramer family error adjustment were made of activity level among rutting periods for young and old males.

The effect of activity level averaged over the entire rutting period, and averaged over each of the early-, peak-, and late-rut weeks, on the amount of mass relative to pre-rut body mass that each dominant male lost was tested using a linear mixed model. The sex ratio of the herd was included as a covariate in all models to control for its influence over male mating behaviour, male-male aggression, and somatic costs for males during the rut. Year and male identity were entered as random terms in all mixed models to account for repeated measurements on individual males and within years, respectively (Machlis et al. 1985). The denominator degrees of freedom (DDF) for the mixed models were calculated according to the Satterthwaite procedure (Littell et al. 2006).

\section{Results}

Over the entire 12 rutting periods, the number of females in a mating group ranged from 1 to 55 (mean $\pm \mathrm{SE}=12.3 \pm 0.345$ ), while the number of males in a group ranged from 1 to 27 (mean \pm $\mathrm{SE}=2.31 \pm 0.082$ ). The sex ratios in the mating groups (ratio of males to females) ranged from 0.02 to 5.4 (mean $\pm \mathrm{SE}=0.29 \pm 0.013$ ); however, there were only 5 out of 414 observation periods when the sex ratio was greater than one. When the sex ratio was smaller than one, the mean mating-group sex ratio was $0.15 \pm 0.32($ mean $\pm \mathrm{SE})$.

Overall, activity level differed both between young and old dominant reindeer males $\left(F_{1,288}\right.$ $=32.27, p<0.001)$ and among the early, peak, and late rut $\left(F_{2,288}=5.11, p=0.0066\right)$; the pattern being age-specific as the interaction between age class and rutting period was also significant $\left(F_{2,288}=4.05, p=0.0185\right)$. We thus carried out further analyses for each age class separately. There were no differences in the activity levels of young male reindeer during the early, peak 


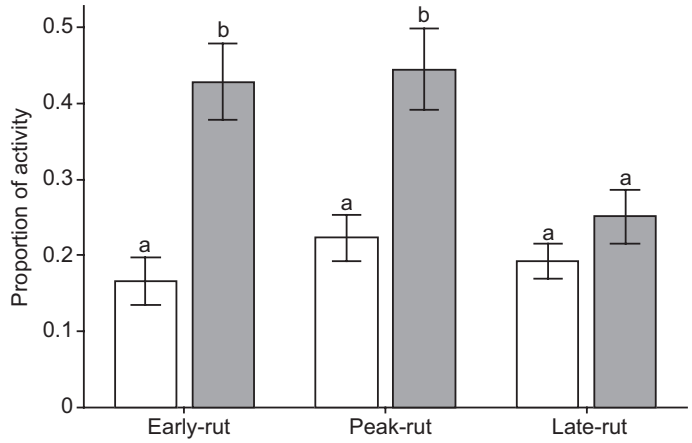

Fig. 1. Mean proportions ( \pm 1 SE) of activity of young (white bars) and old (grey bars) dominant males during the early-, peak-, and late-rut weeks. Means with the same letter are not significantly different according to a Tukey-Kramer multiple comparisons test $(\alpha=0.05)$.

and late rut (all $p>0.05$; Fig. 1). However, for old-male activity levels did differ among periods $\left(F_{2,102}=5.12, p<0.0076\right)$, with activity being significantly higher during the early and peak rut than during late rut (Fig. 1). In addition, activity level of old males was significantly higher than that of young males during the early and peak rut (early rut: estimate $0.253 \pm 0.0514, t_{37}=4.91, p$ $<0.001$; peak rut: estimate $0.207 \pm 0.0581, t_{96}=$ $3.57, p=0.0006$; Fig. 1$)$, but not during the late rut $(p=0.26$; Fig. 1$)$.

When rutting period was not taken into account, we could not detect an effect of male activity level on relative mass loss for either old ( $p=0.218$; Table 2$)$ or young males ( $p=0.09$; Table 2). However, relative mass loss increased with increasing activity level specifically during the early-rut week for young males $\left(F_{1.24}=5.8\right.$, $p=0.024)$, but not for old males, the effect only approaching significance $(p=0.07$; Table 2 and Fig. 2A). Conversely, relative mass loss increased with increasing activity level during the peak-rut week for old $\left(F_{1.22 .9}=9.57, p=0.005\right)$ but not for young males $(p=0.158$; Table 2 and Fig. 2B). Finally, there was no significant effect of male activity level during the late-rut week on the relative mass loss of any males (all $p>0.05$; Table 2). Overall, activity level of males declined as group sex-ratio became more male-biased; for young males, this negative relationship was only significant over the entire rutting period, and in the early and late rut (Table 2).

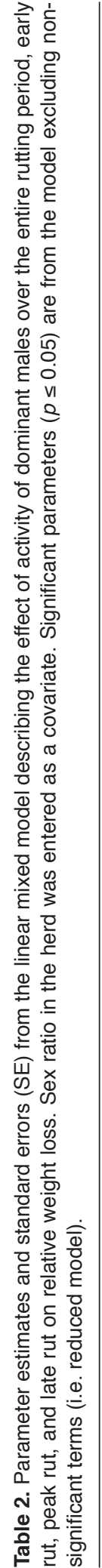



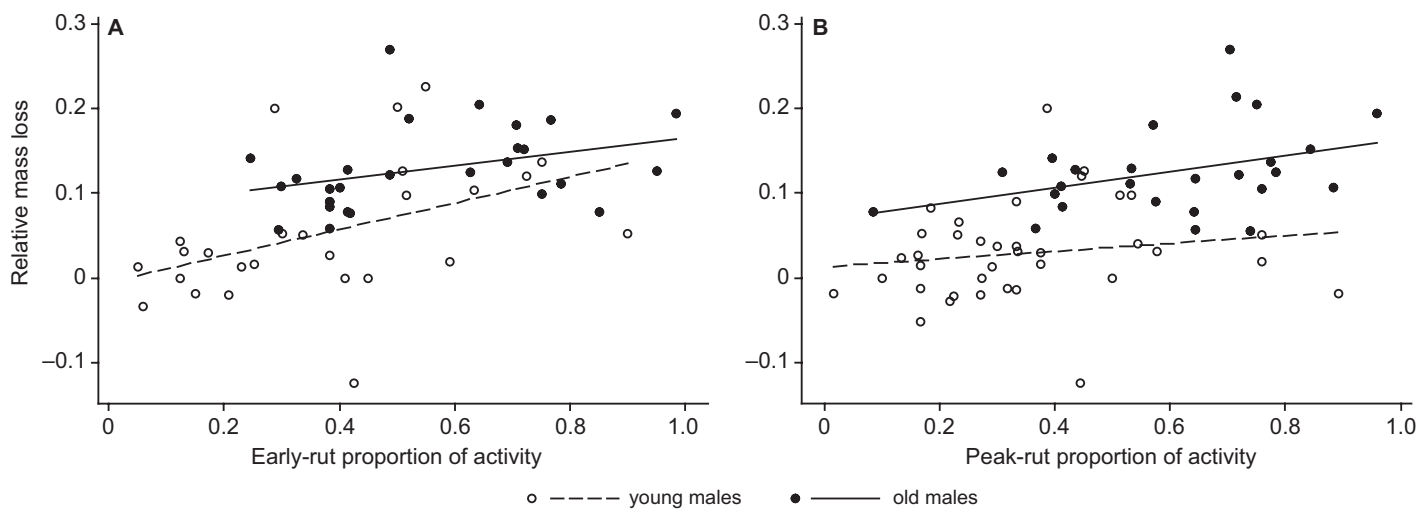

Fig. 2. Relationship between relative mass loss of dominant males and their activity in (A) early rut and (B) peak rut.

\section{Discussion}

We found that activity levels of dominant male reindeer varied with age and rutting period. Activity was higher for old than young dominant males during the early- and peak-rut weeks. Past studies found activity during the mating season to be generally higher for old than for young males (Skogland 1989, Kojola 1991, Mysterud et al. 2004).

During the late-rut week we found that old males reduced their activity level. Decreased activity towards the end of the rut, which has previously been reported for reindeer (Skogland 1989), along with increased feeding are probably methods of compensation for the weight lost during the rut, as low condition at the end of the rutting season can negatively impact future reproductive success and survival (Leader-Williams 1980). It could also be that old males have used up their energy reserves by the end of the rut and are, therefore, physically unable to be active during the final week of the rut (Bobek et al. 1990). However, contrary to Willisch and Ingold (2007) who found that feeding of old male Alpine chamois (Rupicapra rupicapra rupicapra) was higher during the early and late rut than during the peak rut, we observed feeding of old males to be high only during the late rut, but low during the early and peak rut. This result is consistent with our findings that activity level of the old males was high during both the earlyand peak-rut weeks, as there is often a negative relationship between reproductive and maintenance activities, such as feeding (Stearns 1992, Pelletier et al. 2009).
Male activity level over the entire rutting period was not related to mass loss. The fact that males were weighed prior to the start and after the end of the rut may explain why we did not detect an effect. This also may suggest that this indirect measure of reproductive effort (activity level) is not necessarily a good indicator of the somatic costs of reproduction. However, since male activity level varies by period, we examined this relationship within each rutting period. Activity level of old males during the peak rut was positively related to somatic costs, which indicates that the peak-rut week may have the strongest influence on mass loss of old males. We specifically examined standing and walking. Standing behaviour is associated with female defense because it allows a dominant male to watch members of the group and stay alert to wandering females or intruding males (Clutton-Brock et al. 1982, Buschhaus et al. 1990, Willisch \& Ingold 2007, Mainguy \& Côté 2008), while males move during the rut in order to search for receptive females, follow females, and drive them back to the group (Epsmark 1964, Komers et al. 1997, Forsyth et al. 2005). These activities are both associated with significant energetic costs and reduce time available for foraging (Pelletier et al. 2009), which inevitably leads to mass loss or reduced mass gain.

However, activity level during the early-rut week, although high, was not related to somatic costs for old males. Having high body condition reduces the costs associated with performing activity (McElligott et al. 2003, Pelletier 2005); since males are usually in their best condition at 
the beginning of the rut, being active during this time might incur relatively low somatic costs. The fact that the proportion of time spent standing and walking was not related to body mass loss during the early rut might be explained by the other energetically costly activities being performed during that time. Indeed, the early rut is the time when males establish their dominance hierarchy through aggression (Bergerud 1974, Pelletier 2005), and aggressive behaviour is more intense (McElligott et al. 1998, Jennings et al. 2010) and fighting duration is longer (Mattiangeli et al. 1998) in older individuals. Therefore, aggression during the early rut probably has a stronger effect on relative body mass loss than do standing and walking activity. In addition, old males fed more during the early rut than during the peak rut, although the difference was not statistically significant; a similar reduction in foraging from the early to peak rut has been observed in red deer, Cervus elaphus (Mysterud et al. 2008a). It has been proposed that this early-rut extra feeding is a tactic intended to partially compensate for the effects of high activity on body mass loss during the early-rut period (Liu et al. 2009). However, why old males would use this tactic only during the early-rut period is unknown. It is also understood that quality of forage, and therefore foraging efficiency, varies over time (Fryxell 1991). Thus, it is possible that differences in foraging efficiency throughout the mating season cause somatic costs to differ among periods, i.e. if foraging efficiency were higher the during early rut than during the peak rut, this could explain why the activity performed during the early rut does not have an effect on somatic costs.

The results for young males indicated the opposite of what was found for old males. Activity level during the early-rut period had a positive effect on the amount of weight young males lost over the rut, whereas activity level during the peak-rut was unrelated to somatic costs. Young males fed more during the peak rut, although the difference between the early and peak rut was not significant; this slight increase in feeding during the peak rut might have compensated for the energetic costs associated with activity during this period. Since the reproductive effort of old males is highest during the peak-rut period, young males may avoid pursuing females during this time as it would provoke aggression from old males. Similarly, Singer and Zeigenfuss (2002) found that young male Dall sheep (Ovis dalli) increase their reproductive effort when adult males are scarce or absent. Thus, young male reindeer might resort to an alternative mating tactic, whereby they perform their most energetically costly activities earlier in the mating season when competition from old males is less intense. Another explanation is that young males are not able to schedule their reproductive effort to coincide with peak oestrus as old males do because of their inexperience (Mysterud et al. 2008b). The inexperience of young males manifests itself as undeveloped social rutting behaviour, such as harassment of females, which can induce stress and mass loss in females (Holand et al. 2006). It is possible that precise timing of reproductive effort is another learned skill that improves with age. However, the reason why young males in this herd devoted most of their reproductive effort to the early rut rather than to the late rut, when old males became exhausted as Mysterud et al. (2008b) found, remains unclear and warrants further research.

In concordance with many studies, we found that during the mating season old males are more active and feed less than young males (Skogland 1989, Miquelle 1990, Apollonio \& Di Vittorio 2004, Mainguy \& Côté 2008). Our sample consisted of only the dominant males of mating groups; therefore, we determined that although dominant males are typically the most active during the rut, this age-specific activity pattern remains. The direct (relative body mass loss) and indirect (activity level) measures of male reproductive effort during the mating season were positively related to each other during different periods of the rut depending on male age - early rut for young males, and peak rut for old males. For both old and young males, activity levels averaged over the entire mating season were never significantly related to relative body mass loss. This indicates that activity level over the entire mating season might not be a good proxy for reproductive cost in male reindeer, since activity level changes over the course of the rut. Furthermore, the timing of activity levels differs between young and old males; therefore, activity in young and old males should be exam- 
ined separately. These results may influence the way in which reproductive effort of male mammals is measured in future studies.

\section{Acknowledgements}

We gratefully acknowledge the financial support of the Natural Sciences and Engineering Research Council of Canada (scholarship to E.M.T and research grant to R.B.W) and the Northern Scientific Training Program. Thanks also to Jean-Michel Gaillard, James Grant and 2 anonymous reviewers for comments that improved this manuscript. We thank all students, assistants, and volunteers who have contributed to our research over the past 14 years. We are grateful to the Kutuharju Field Reindeer Station (Kaamanen, Finland), to Mika Tervonen and Heikki Törmänen for assistance and logistic support.

\section{References}

Apollonio, M. \& Di Vittorio, I. 2004: Feeding and reproductive behaviour in fallow bucks (Dama dama). - Naturwissenschaften 91: 579-584.

Apollonio, M., Festa-Bianchet, M., Mari, F., Mattioli, S. \& Sarno, B. 1992: To lek or not to lek: mating strategies of male fallow deer. - Behav. Ecol. 3: 25-31.

Barboza, P. S., Hartbauer, D. W., Hauer, W. E. \& Blake, J. E. 2004: Polygynous mating impairs body condition and homeostasis in male reindeer (Rangifer tarandus tarandus). - J. Comp. Physiol. B 174: 309-317.

Bergerud, A. T. 1974: Rutting behaviour of Newfoundland caribou. - In: Geist, V. \& Walther, F. (eds.), The behaviour of ungulates and its relation to management: 395. IUCN, Morges, Switzerland.

Bobek, B., Perzanowski, K. \& Weiner, J. 1990: Energyexpenditure for reproduction in male red deer. $-J$. Mammal. 71: 230-232.

Buschhaus, N. L., Lagory, K. E. \& Taylor, D. H. 1990: Behaviour in an introduced population of fallow deer during the rut. - Am. Midl. Nat. 124: 318-329.

Clutton-Brock, T. H. 1984: Reproductive effort and terminal investment in iteroparous animals. - Am. Nat. 123: 212-229.

Clutton-Brock, T. H., Guinness, F. E. \& Albon, S. D. 1982: Red deer: behavior and ecology of two sexes. - The University of Chicago Press, Chicago.

Emlen, S. T. \& Oring, L. W. 1977: Ecology, sexual selection, and the evolution of mating systems. - Science 197: 215-223.

Epsmark, Y. 1964: Rutting behaviour in reindeer (Rangifer tarandus). - Anim. Behav. 12: 159-163.

Fisher, R. 1930: The genetical theory of natural selection. Oxford University Press, Oxford.

Forsyth, D. M., Duncan, R. P., Tustin, K. G. \& Gaillard, J. M. 2005: A substantial energetic cost to male reproduction in a sexually dimorphic ungulate. - Ecology 86: 2154-2163.
Fryxell, J. M. 1991: Forage quality and aggregation by large herbivores. - Am. Nat. 138: 478-498.

Galimberti, F., Sanvito, S., Braschi, C. \& Boitani, L. 2007: The cost of success: reproductive effort in male southern elephant seals (Mirounga leonina). - Behav. Ecol. Sociobiol. 62: 159-171.

Holand, Ø., Weladji, R. B. \& Røed, K. 2011: Rangifer mating system - revisited. - In: 13th Arctic Ungulate Conference 'Challenges of Managing Northern Ungulates', August 22 to 26, 2011, Yellowknife, Northwest Territories, Canada: 43. The International Ungulate Society.

Holand, Ø., Weladji, R. B., Røed, K. H., Gjøstein, H., Kumpula, J., Gaillard, J. M., Smith, M. E. \& Nieminen, M. 2006: Male age structure influences females' mass change during rut in a polygynous ungulate: the reindeer (Rangifer tarandus). - Behav. Ecol. Sociobiol. 59: 682-688.

Jennings, D. J., Carlin, C. M., Hayden, T. J. \& Gammell, M. P. 2010. Investment in fighting in relation to body condition, age and dominance rank in the male fallow deer, Dama dama. - Anim. Behav. 79: 1293-1300.

Jennings, D. J., Gammell, M. P., Carlin, C. M. \& Hayden, T. J. 2004: Effect of body weight, antler length, resource value and experience on fight duration and intensity in fallow deer. - Anim. Behav. 68: 213-221.

Jönsson, K. I. 1997: Capital and income breeding as alternative tactics of resource use in reproduction. - Oikos 78: 57.

Kojola, I. 1991: Influence of age on the reproductive effort of male reindeer. - J. Mammal. 72: 208-210.

Komers, P. E., Birgersson, B. \& Ekvall, K. 1999: Timing of estrus in fallow deer is adjusted to the age of available mates. - Am. Nat. 153: 431-436.

Komers, P. E., Pelabon, C. \& Stenstrom, D. 1997: Age at first reproduction in male fallow deer: age-specific versus dominance-specific behaviors. - Behav. Ecol. 8: 456-462.

Leader-Williams, N. 1980: Population dynamics and mortality of reindeer introduced into South Georgia. $-J$. Wildl. Manage. 44: 640-657.

Littell, R. C., Milliken, G. A., Stroup, W. W., Wolfinger, R. D. \& Schabenberger, O. 2006: SAS for mixed models, 2nd ed. - SAS Institute Inc., Cary.

Liu, B. W., Qian, Z. Q., Zhang, B., Liu, S. T. \& Li, M. 2009: Diurnal activity budgets and energy balance strategy of Mongolian gazelle (Procapra gutturosa) before, during and after the rut around Dalai Lake, inner Mongolia. Zool. Res. 30: 694-698.

Machlis, L., Dodd, P. W. D. \& Fentress, J. C. 1985: The pooling fallacy - problems arising when individuals contribute more than one obseration to the data set. $-J$. Comp. Ethol. 68: 201-214.

Mainguy, J. \& Côté, S. D. 2008: Age- and state-dependent reproductive effort in male mountain goats, Oreamnos americanus. - Behav. Ecol. Sociobiol. 62: 935-943.

Martin, P. \& Bateson, P. 2007: Measuring behaviour: an introductory guide, 3rd ed. - Cambridge University Press, Cambridge, UK.

McElligott, A. G., Naulty, F., Clarke, W. V. \& Hayden, T. J. 2003: The somatic cost of reproduction: what determines reproductive effort in prime-aged fallow bucks? - Evol. 
Ecol.Res. 5: 1239-1250.

Michener, G. R. \& McLean, I. G. 1996: Reproductive behaviour and operational sex ratio in Richardson's ground squirrels. - Anim. Behav. 52: 743-758.

Miquelle, D. G. 1990: Why don't bull moose eat during the rut? - Behav. Ecol. Sociobiol. 27: 145-151.

Mysterud, A., Bonenfant, C., Loe, L. E., Langvatn, R., Yoccoz, N. G. \& Stenseth, N. C. 2008a: Age-specific feeding cessation in male red deer during the rut. $-J$. Zool. 275: 407-412.

Mysterud, A., Bonenfant, C., Loe, L. E., Langvatn, R., Yoccoz, N. G. \& Stenseth, N. C. 2008b: The timing of male reproductive effort relative to female ovulation in a capital breeder. - J. Anim. Ecol. 77: 469-477.

Mysterud, A., Holand, O., Roed, K. H., Gjostein, H., Kumpula, J. \& Nieminen, M. 2003: Effects of age, density and sex ratio on reproductive effort in male reindeer (Rangifer tarandus). - J. Zool. 261: 341-344.

Mysterud, A., Langvatn, R. \& Stenseth, N. C. 2004: Patterns of reproductive effort in male ungulates. $-J$. Zool. 264: 209-215.

Mysterud, A., Roed, K. H., Holand, O., Yoccoz, N. G. \& Nieminen, M. 2009: Age-related gestation length adjustment in a large iteroparous mammal at northern latitude. - J. Anim. Ecol. 78: 1002-1006.

Mysterud, A., Solberg, E. J. \& Yoccoz, N. G. 2005: Ageing and reproductive effort in male moose under variable levels of intrasexual competition. - J. Anim. Ecol. 74: 742-754

Neuhaus, P. \& Pelletier, N. 2001: Mortality in relation to season, age, sex, and reproduction in Columbian ground squirrels (Spermophilus columbianus). - Can. J. Zool. 79: 465-470.

Nilsson, J. A. \& Svensson, E. 1996: The cost of reproduction: a new link between current reproductive effort and future reproductive success. - Proc. R. Soc. Lond. B 263: 711-714.

Pelletier, F. 2005: Foraging time of rutting bighorn rams varies with individual behavior, not mating tactic. Behav. Ecol. 16: 280-285.
Pelletier, F., Mainguy, J. \& Cote, S. D. 2009: Rut-induced hypophagia in male bighorn sheep and mountain goats: foraging under time budget constraints. - Ethology 115: $141-151$

Preston, B. T., Stevenson, I. R. \& Wilson, K. 2003: Soay rams target reproductive activity towards promiscuous females' optimal insemination period. - Proc. R. Soc. Lond. B 270: 2073-2078.

Roed, K. H., Holand, Ø., Smith, M. E., Gjostein, H., Kumpula, J. \& Nieminen, M. 2002: Reproductive success in reindeer males in a herd with varying sex ratio. $-\mathrm{Mol}$. Ecol. 11: 1239-1243.

Saunders, F. C., McElligott, A. G., Safi, K. \& Hayden, T. J. 2005: Mating tactics of male feral goats (Capra hircus): risks and benefits. - Acta Ethol. 8: 103-110.

Singer, F. J. \& Zeigenfuss, L. C. 2002: Influence of trophy hunting and horn size on mating behavior and survivorship of mountain sheep. - J. Mammal. 83: 682-698.

Skogland, T. 1989: Comparative social organization of wild reindeer in relation to food, mates and predator avoidance. - Adv. Ethol. 29: 1-74.

Stearns, S. C. 1992: The evolution of life histories. - Oxford University Press, Oxford.

Tennenhouse, E. M., Weladji, R. B., Holand, Ø., Røed, K. H. \& Nieminen, M. 2010: Mating group composition influence somatic costs and activity in rutting dominant male reindeer (Rangifer tarandus). - Behav. Ecol. Sociobiol. 65: 287-295.

Vannoni, E. \& McElligott, A. G. 2009: Fallow bucks get hoarse: vocal fatigue as a possible signal to conspecifics. - Anim. Behav. 78: 3-10.

Willisch, C. S. \& Ingold, P. 2007: Feeding or resting? The strategy of rutting male Alpine chamois. - Ethology 113: $97-104$.

Willisch, C. S. \& Neuhaus, P. 2009: Alternative mating tactics and their impact on survival in adult male alpine ibex (Capra ibex ibex). - J. Mammal. 90: 1421-1430.

Yoccoz, N. G., Mysterud, A., Langvatn, R. \& Stenseth, N. C. 2002: Age- and density-dependent reproductive effort in male red deer. - Proc. R. Soc. Lond. B 269: 1523-1528. 